\title{
The Effect of Mental Health Status on the Quality of Life of Faculty of Medicine Students during the Pandemic Coronavirus Disease 2019 Period
}

\author{
Agustina Arundina Triharja Tejoyuwono ${ }^{1 *}$ (D), Rangga Putra Nugraha ${ }^{2}$ iD, Faisal Kholid Fahdi ${ }^{3}$ iD \\ ${ }^{1}$ Department of Community Medicine, Faculty of Medicine, Tanjungpura University, Pontianak, West Kalimantan, Indonesia; \\ ${ }^{2}$ Department of Otorhinolaryngology Head and Neck Surgery, Faculty of Medicine, Tanjungpura University, Pontianak, West \\ Kalimantan, Indonesia; ${ }^{3}$ Department of Community Health Nursing, Faculty of Medicine, Tanjungpura University, Pontianak, \\ West Kalimantan, Indonesia
}

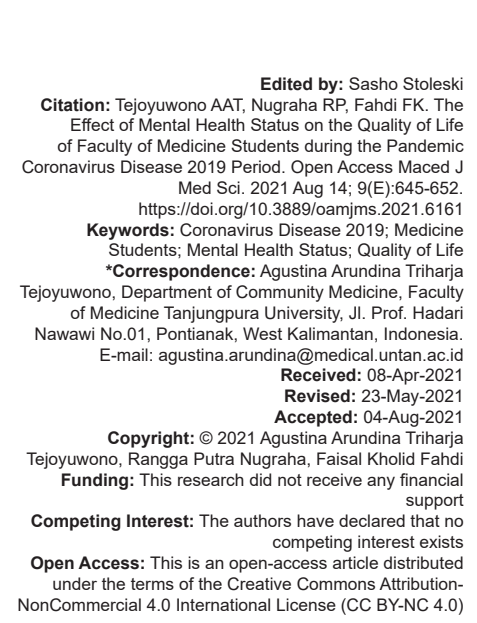

Introduction

Mental health becomes one of essential things to pay attention to, especially during the pandemic COVID-19 period. A good mental health condition is when the mind feels serene and peaceful so that an individual can enjoy daily life and appreciate other people, be able to use abilities and self-potency in facing the challenges of life [1]. Depression and anxiety are emotional mental illnesses, while stress is a psychological distress condition that can lead to severe psychological illness (psychosis), if it is late to be detected and treated [2]. Based on the prevalence of stress, anxiety, and depression occurrence, during pandemic COVID-19 period, people from Asian races are the most in number who suffer from anxiety $(32.9 \%$; $\mathrm{Cl}$ : 28.2-37.9) and depression (35.3\%; Cl: 27.3-44.1) compared to people from other races. Stress occurred mostly on the population in Europe (31.9\%; Cl: 23.1-42.2) [3].

\begin{abstract}
BACKGROUND: The spread of Coronavirus Disease 2019 (COVID-19) disease which has not been balanced with any research that examines the influence of both factors. during COVID-19 period.

METHODS: This is a cross-sectional survey on 361 students from Faculty of Medicine Tanjungpura University.

RESULT: The students' mental health status was dominantly on the normal category with depression domain by 323 students $(89.5 \%)$, anxiety domain by 311 students $(86.1 \%)$, and stress domain by 343 students $(95 \%)$. The health $(92.5 \%)$, social relationships $(50.7 \%)$, and environment $(78.7 \%)$. There was significant effect of mental health health status domain depression $(p=0.051)$ and anxiety $(p=0.881)$ toward the environment aspect.

CONCLUSION: Students' mental health status in this research belongs to the category normal with moderate leve in quality of life. To compare, there was a significant effect of mental health status toward the quality of life domains. The good application of self-coping mechanisms and the social encouragement from the environment is suitable intervention strategies during the pandemic COVID-19 period.
\end{abstract} contagious disease caused by a new type of Coronavirus. Up until now, the spread of COVID-19 is occurring in almost all parts of the world. It started by reported pneumonia cases whose etiology is unknown in Wuhan, China in the end of 2019. The disease outbreak made the World Health Organization (WHO) announce COVID-19 as PHEIC (Public Health Emergency of International Concern) on 30 January 2020. Indonesia reported its first case of COVID-19 on March 2, 2020, and later the number of cases kept increasing until today [4].

As of today, the researches on specific medicine as well as the effectiveness and efficiency of COVID-19 vaccines on public are still in progress and yet to get significant results [5]. However, it is actually the high risk of contamination, the death rate varied in different regions, and the absence of standard protocols that became the factors causing fear and mental health deterioration of people [6]. In the end, the 
fear caused by COVID-19 could affect the ability of a person to survive from uncertainty, meaning of life, life satisfaction, expectations, and mental condition; this could cause an increase in anxiety or depression that are correlated with the quality of life [7], [8].

During the pandemic COVID-19 period, there have been a number of researches conducted to examine mental disorders such as depression, anxiety, and stress on medical students [9], [10], [11], [12], [13], [14], [15]. In Indonesia, $48.4 \%$ ofAirlangga Universitymedical students had depression linked to age, sex, and batch year [16]. On nursing students, around $12.2 \%$ of them suffered from severe depression and $25.7 \%$ had mild mood disorder [17]. This condition was also observed in nursing academy students in which $21.1 \%$ had light depression and $17 \%$ had moderate depression [18]. Eventually, that could lead to the fatigue and burnout syndrome during pandemic COVID-19 [19].

Research conducted in the Faculty of Medicine Tanjungpura University (FK UNTAN) showed that most of medical students there felt no anxiety at all, but there were some things they worried during the pandemic COVID19 period [20]. The COVID-19 pandemic happened in an instant, causing students' mental health to deteriorate. As a result, it is worried that the students' quality of life could be affected. However, there is no research that correlates between mental health and the quality of life of medical students as of yet. Therefore, this study was to analyze the mental health status on the quality of life among medicine students during COVID-19 period.

\section{Methods}

This research utilized cross-sectional study design, conducted from June 2020 to November 2020 at FK UNTAN. 361 students gave consent to be the subjects of research with non-probability sampling method and voluntary design type. The data collection was carried out using questionnaires given out online. This research had received codes of conduct from FK UNTAN on June 18, 2020 no. 2961/UN22.9/TA/2020.

Depression Anxiety Stress Scale (DASS) questionnaire made up of 21 items in the Indonesian version [21]; it is used to score mental health status of the students. This questionnaire is comprised 21 items, using Likert scale. Depression status is classified into normal (0-9), mild (10-13), moderate (14-20), severe (21-27), and very severe (>28). Anxiety status is classified into normal (0-7), mild (8-9), moderate $(10-14)$, severe (15-19), and very severe $(>20)$. Stress is classified into normal (0-14), mild (15-18), moderate (19-25), severe (26-28), and very severe (>29).

Students' Quality of Life is scored using WHOQOL-BREF questionnaire [22]. This questionnaire contained four domain scoring aspects of quality of life: Physical health, psychological health, social relationships, and environment domain (Table 1). The instruments of quality of life are scored using Likert scale; each domain is scored, then the scores are summed up; after that, the scores were transformed into a table with scale $0-100$. Score 0 is for the lowest quality and 100 for the highest quality. The data were served in form of table, with dependent variable in form of ratio data (WHOQOL-BREF) and independent variable being categorical data (DASS). The data were analyzed using Kruskal-Wallis statistical analysis because the distribution of results is abnormal.

\section{Results}

In this research, out of 361 students willing to participate, 268 students $(74.2 \%)$ are female students aged under 20 years old (57.6\%). Undergraduate degree students made up the most respondents (80.6\%) compared to professional degrees (19.4\%), mostly coming from batch 2019 students (140 students), and batch 2018 came in second (80 students). This research was participated by six study programs in FK UNTAN; they are medicine study program with 133 students $(36.8 \%)$, nursing study program with 81 students $(22.4 \%)$, pharmacy study program with 77 students $(21.3 \%)$, medicine professional degree with 20 students $(5.5 \%)$, nurse professional degree with 38 students $(10.5 \%)$, and pharmacist professional degree with 12 students $(3.3 \%)$. These numbers were relatively representative as research samples from all study programs, making it representative to the desired population.

In general, the mental health status of FK UNTAN students belongs to the normal category, which is on the category depression by 323 students

Table 1: Aspects of quality of life measurement in WHOQOLBREF domain

\begin{tabular}{ll}
\hline Domain & Aspects \\
\hline Physical Health & Activities of Daily Living \\
& Dependence on Medicinal substances \\
& Energy and Fatigue \\
& Mobility \\
& Pain and discomfort \\
Sleep and rest & Work capacity \\
& Body image and Appearance \\
& Negative Feeling \\
Psychological Health & Positive Feeling \\
& Self-esteem \\
& Thirituality/Religion/Beliefs \\
& Personal realationships \\
& Social support \\
Social Relationships & Sexual activity \\
& Financial resource \\
& Freedom, physical safety, and security \\
Environment & Access to healthcare \\
& Home environment \\
& Opportunities for acquiring new information and skills \\
& Opportunities for recreation \\
& Physical environments \\
Transport
\end{tabular}




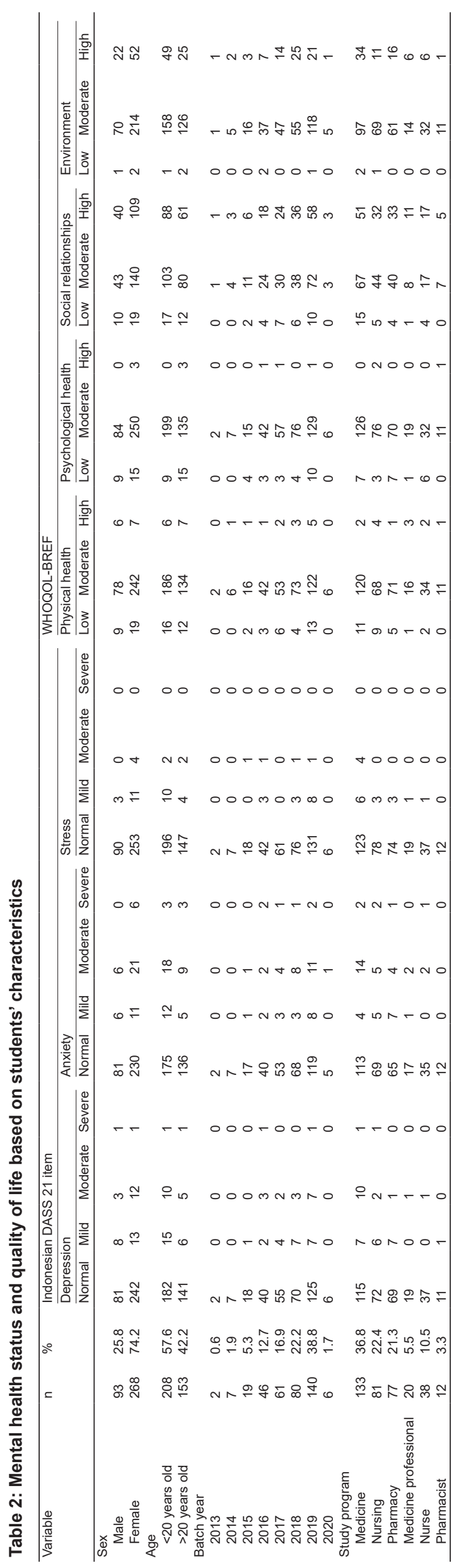

$(89.5 \%)$, category anxiety by 311 students $(86.1 \%)$, and category stress by 343 students $(95 \%)$. The pandemic COVID-19 did not give much influence on the medicine study program in the FK UNTAN. This is reflected from the results in Table 2 that showed that only $0.6 \%$ of the students who suffered from severe depression, and $1.7 \%$ suffered from severe anxiety. Nevertheless, it is still important to anticipate the influence of the continuous pandemic condition that could lead to the deterioration of mental health status. This was shown by the students whose depression, anxiety and stress status belonged to category mild to moderate.

Female students were more in number in the category of mild depression to severe depression $(7.20 \%)$, anxiety $(10.53 \%)$, and stress $(4.16 \%)$ compared to male students. Mental disorder from mild - severe state also occurred on medical study program students aged $<20$ years old $(7.20 \%)$ and on students from batch 2019 (4.16\%). Among all study programs, medicine study program students were the most in number of students who suffered from depression (4.99\%), anxiety $(5.54 \%)$, and stress $(2.27 \%)$.

Based on the results of quality of life measurement, most of the medical students are in the category of moderate quality on every single measured domain, namely, physical health $(88.6 \%)$, psychological health $(92.5 \%)$, social relationships (50.7\%), and environment $(78.7 \%)$. However, low level of quality of life is also observed at $7.8 \%$ in physical health, $3.6 \%$ in psychological health, and $8 \%$ in social relationships. The highest score for quality of life is in the environment domain $(20.5 \%)$ compared to other domains. Furthermore, when the domains were compared against each other, many students have low level of quality of life on domain physical health and psychological health, while their high scores were on social relationships domain and environment domain.

Most of medical students of UNTAN are in normal mental condition with a moderate quality of life domain. When comparing the number of students with low and high quality of life, most of the students whose conditions of depression, anxiety, and stress in normal category had low physical health and psychological health domains. In contrast, their quality of life in the domain of social relationships and environment is higher with normal mental conditions. For students with conditions of moderate to severe depression and stress, more students had low status than high status in the domain of physical health and social relationships, but it was the opposite on the environment domain. Furthermore, in the conditions of moderate to severe anxiety, more people have a high status on the domain of social relationships and environment. Still on those statuses, there were more students with low physical health compared to those with high anxiety.

The quality of psychological health will not be affected by the mental condition of the students at all. However, the quality of social relationships will only be 
affected if depression and stress occur, but not anxiety. In conclusion, the condition of depression, anxiety, and stress on moderate to severe will cause a decrease in the physical health domain of students without affecting environment domain. Based on the test to discover the influence between the variables of mental conditions and quality of life, there was a significant influence between depression and the quality of life on physical health domain ( $p$ : 0.000), psychological health domain (p: 0.000), and social relationships domain ( $p: 0.000)$. Anxiety also affected the physical health domain ( $p$ : 0.043), psychological health domain ( $p: 0.000)$, and social relationship domain ( $p: 0.001)$. In stress variable, there was a significant effect on all quality of life domains, but there was no significant effect of depression and anxiety status on environment domain ( $p>0.05)$ (Table 3).

\section{Discussion}

\section{The effect of pandemic on mental health and quality of life}

Pandemic COVID-19 is deemed as a traumatic condition that could cause fear/paranoia against COVID-19, insecurities, anxiety exacerbation, and hyper-alerted condition [7], [23]. The tragic occurrence that caused panicking, while there were social demands and roles that must be maintained which can prompt an increase of depression in the society [24]. In the end, this pandemic condition will affect the quality of life of a person. The quality of life is a perception of values/ ways of life viewed from cultural context, behavior, and valuing system of place for living; it correlates with standard of life, expectancy, happiness, and individual value toward their position in life [25]. The disorders that emerge are the feeling of anger, disappointment, irritability, and prolonged sadness could lead to the decrease of function which affects people during the pandemic [23], [26].

For medical students, the pandemic would cause somatic symptoms such as the decrease of sleep quality, losing spirit, concentration problems, negative feelings on oneself, and the increase of depression, anxiety, and stress. The somatic symptoms also include worsened relationships with other people, such as less frequent interactions among family members/friends and the emergence of negative stigma toward COVID-19 patients [9], [14]. On medical students, contracting and transmitting the virus to family becomes the cause of anxiety, breach in relationships among family members and friends, and a delay in finishing studies. In addition, the effect on the academic performance and clinical skills became the basis of anxiety [27]. Those conditions will affect the scores of the students on the aspects of quality of physical health and psychological health domain, shown by the number of medical students who have a lower quality of life in both domains during the pandemic period.

Although the pandemic condition affected the students' quality of life, the mental health status (depression, anxiety, and stress) of medical students of UNTAN in this research was in the normal category. This is due to good knowledge/cognition and correct information regarding the transmission, treatment, prognosis, and prevention of COVID-19, which became positive ways to prevent anxiety during the pandemic period [13]. The desire of medical students of UNTAN to seek information is very high; social media are the main type of information source accessed, and the amount of information obtained did not cause anxiety for them [20].

In addition, living with parents, high social relationship in the society, and the economic stability of the family increased optimism and became factors that can hinder students from mental issues [17], [28], [29], [30]. These factors are positive conditions that affected the quality of life in the social

Table 3: Impact of mental health status toward quality of life domains

\begin{tabular}{|c|c|c|c|c|c|c|c|c|c|c|c|c|}
\hline \multirow{2}{*}{ Variable } & \multicolumn{3}{|c|}{ Physical health } & \multicolumn{3}{|c|}{ Psychological health } & \multicolumn{3}{|c|}{ Social relationships } & \multicolumn{3}{|c|}{ Environment } \\
\hline & Low & Moderate & High & Low & Moderate & High & Low & Moderate & High & Low & Moderate & High \\
\hline \multicolumn{13}{|l|}{ Depression } \\
\hline Normal & 21 & 290 & 12 & 24 & 297 & 2 & 17 & 162 & 144 & 3 & 252 & 68 \\
\hline Mild & 3 & 17 & 1 & 0 & 20 & 1 & 6 & 12 & 3 & 0 & 18 & 3 \\
\hline Moderate & 3 & 12 & 0 & 0 & 15 & 0 & 5 & 9 & 1 & 0 & 12 & 3 \\
\hline Severe & 1 & 1 & 0 & 0 & 2 & 0 & 1 & 0 & 1 & 0 & 2 & 0 \\
\hline$x^{2}$ & 20.598 & & & 24.96 & & & 29.80 & & & 7.769 & & \\
\hline $\mathrm{p}$-value & $0.000^{*}$ & & & $0.000^{\prime}$ & & & 0.000 & & & 0.0510 & & \\
\hline \multicolumn{13}{|l|}{ Anxiety } \\
\hline Normal & 21 & 278 & 12 & 24 & 284 & 3 & 19 & 156 & 136 & 3 & 246 & 62 \\
\hline Mild & 2 & 15 & 0 & 0 & 17 & 0 & 2 & 11 & 4 & 0 & 13 & 4 \\
\hline Moderate & 3 & 23 & 1 & 0 & 27 & 0 & 8 & 12 & 7 & 0 & 21 & 6 \\
\hline Severe & 2 & 4 & 0 & 0 & 6 & 0 & 0 & 4 & 2 & 0 & 4 & 2 \\
\hline$x^{2}$ & 8.155 & & & 23.61 & & & 16.14 & & & 0.665 & & \\
\hline $\mathrm{p}$-value & $0.043^{*}$ & & & $0.000^{\prime}$ & & & 0.001 & & & 0.8810 & & \\
\hline \multicolumn{13}{|l|}{ Stress } \\
\hline Normal & 24 & 306 & 13 & 24 & 316 & 3 & 23 & 173 & 147 & 2 & 268 & 73 \\
\hline Mild & 2 & 12 & 0 & 0 & 14 & 0 & 4 & 8 & 2 & 1 & 13 & 0 \\
\hline Moderate & 2 & 2 & 0 & 0 & 4 & 0 & 2 & 2 & 0 & 0 & 3 & 1 \\
\hline Severe & 0 & 0 & 0 & 0 & 0 & 0 & 0 & 0 & 0 & 0 & 0 & 0 \\
\hline$x^{2}$ & 8.395 & & & 13.30 & & & 18.24 & & & 7.673 & & \\
\hline$p$-value & $0.015^{*}$ & & & 0.001 & & & 0.000 & & & $0.022^{\star}$ & & \\
\hline
\end{tabular}


relationships and environment domains. On the opposite, this factor was also a worrying thing for medical students of Tanjungpura University. The main concerns of medical students of Tanjungpura University were the possibility of transmission of COVID-19 to themselves and their families, an unstable economic condition of the family as an effect of the pandemic, and the switch to online learning method [20], despite the results of research on the quality of life of students in the social relationships and environment domain being unproblematic.

Being young in age could be both positive and negative factors for the students' mental health status. The over-restriction of social distancing protocols could affect the adherence to younger age groups. The implementation of quarantine during the pandemic COVID-19 created negative psychological effects. Confusion and anger were the symptoms of posttraumatic stress. Fear, frustration, boredom, inadequate supplies, insufficient information, financial loses, and stigmas were the effects of quarantine [31]. However, in the younger age group, the curiosity for multiple sources of information about COVID-19 is higher [28], and this would later promote the preventive behaviors and hinder the spread of the virus to other people [32].

Female group is prone to having mental health problems the most [11], [15], [29], [33], [34], especially those who live in urban areas, those who have chronic illnesses, and those who have a history of mental disorders [35]. This is because women are very vulnerable to stressors as well as changes that occur around them, and they possess poor coping skill [9], [36], [37]. The feelings of relating/being responsive to their social environment (pro-social) and the feeling of optimism and empathy are more relatable and important in the daily life of women compared to men [38]. If depression occurs in women, it will result in hormonal changes that trigger anxiety and also affect the quality of sleep, eating, and headaches [39], [40]. This condition also happened to medical students of Tanjungpura University during the pandemic COVID-19 period. Even though more female students had mental health problems, but it did not affect their clinical conditions. This could be due to the success of situation coping mechanisms and good rational thinking skills [11].

Stress status the aspect that affects the quality of life of students the most during the COVID19 pandemic. Changes in the learning method into online lectures are the major factor causing stress for medical students, which is made worse by the struggles to learn, inadequate online course materials, inability ins studying time management, and the difficulty in concentrating during online lectures [41]. The negative factors of online lectures are viewed to lead to extended length of study in university, resulting in academic performance and will eventually make them incompetent doctors [27]. Stress condition suffered by the students will increase pessimism attitude in facing the pandemic condition that later will reduce their self-esteem towards their surroundings, affect the physical health, reduce motivation and ability to think and work, and affect their relationships with people around them [42], [43], [44].

\section{Methods of improving mental health and quality of life during the pandemic period}

Intervention strategies by implementing good self-coping mechanisms and good social-environmental support are considered to be able to reduce anxiety relating to a person's health status, especially during the COVID-19 pandemic [45], [46]. Improvement of selfresilience will reduce the effects of fear of the coronavirus in the conditions of depression, anxiety and stress [47]. A sense of optimism will help increase the life-acceptance of stress of someone with depressive symptoms [42]. For nurses, the resilience to the COVID-19 epidemic and the family that functions well will reduce stress, anxiety and depression by 2.4 times. In addition, the high spiritual support will reduce depression by 2 times [48].

Several actions have been attempted to reduce mental health problems in the general public and university students. Doing physical activity, attending online counseling services or training in stress-coping skills, and doing relaxation activities will help students build resistance to stressors [17], [49], [50], [51], [52]. Social support will have a greater effect on improving the quality of life than a person's mental well-being during the pandemic COVID-19 period [7]. In addition, doing fun activities such as playing games is considered helpful to relieve and reduce the stress caused by struggles of the students during the pandemic period [53].

Adapting to change, getting used to learning independently, looking for supportive learning locations, and doing other productive activities are the choices for nursing and midwifery students at Nahdlatul Ulama University Surabaya to deal with stress from academic matters that occurred during the COVID-19 pandemic [43]. The implementation of coping mechanisms considered the most effective in reducing stress in medical students is to get closer to God and do spiritual meditation [41].

A person's religiosity during the pandemic will reduce depression and stress. On the other hand, a negative attitude towards religiosity will cause mental health problems and fear of COVID-19 [54]. At the beginning of the pandemic period in Indonesia, people thought that the application of social restrictions had an effect on the opportunity to do religious activities. Religious leaders asked the public to implement health protocols, adjust the practice of worship without leaving the principles of their respective religions. The solution to the situation during the pandemic is thought as creating the feeling of security and comfort in the 
community without causing bigger health problems [55]. Praying and carrying out religious practices were deemed able to reduce anxiety and to provide a sense of calm. This view rose due to the increased acceptance of the situation and the assumption that the COVID-19 pandemic occurred because of God's will [56].

The Students of Gunung Djati University deemed that dzikir practice is a spiritual exercise that made the students calm and be able to control themselves, to overcome anxiety, to think positively and to be optimistic about the future [57]. In a research conducted on the pharmacy students of UIN Malang, there was no change in religious practices during the pandemic, but an increase occurred in things that reflect human values such as giving alms and doing filial piety to their parents in order to get blessings and safety. Besides, the students also listened to more preaching and reading the Koran more frequently. These practices created a sense of peace, safety and calmness during the COVID-19 pandemic [58].

\section{Conclusion}

The depression, anxiety, and stress status medical students UNTAN were in the normal category with the degree of quality of life mostly in the moderate category. Female students from medicine study programs who are aged $<20$ years were more likely to experience depression, anxiety and stress in the mildsevere category. The quality of life assessment resulted in low category in the domain of physical health and psychological health, while the quality of life is high in social and environmental relationships domains. Most of the medical students UNTAN were in normal mental status with quality of life in moderate category. Depression and anxiety aspects had correlations with the quality of life in the domains of physical health, psychological health, and social relationships. Stress aspect affected all domains of quality of life, but there was no significant effect of depression and anxiety on the environment domain of quality of life. The pandemic period that would likely continue in a long term can create rooms for further evaluation of mental health conditions. The level changes in quality of life domains needs to be observed, and it is hoped that there would be further researches in depth regarding the effect strength of DASS toward QOL as well as other risk factors that may have effect on it.

\section{References}

1. Santoso MB. Kesehatan mental dalam perspektif pekerjaan sosial. Share Soc Work J. 2016;6(1):148-53. https://doi. org/10.24198/share.v6i1.13160

2. Ayuningtyas $D$, Misnaniarti M, Rayhani M. Analisis situasi kesehatan mental pada masyarakat di Indonesia dan strategi penanggulangannya. J IImu Kesehat Masy. 2018;9(1):1-10. https://doi.org/10.26553/jikm.2018.9.1.1-10

3. Salari N, Hosseinian-Far A, Jalali R, Vaisi-Raygani A Rasoulpoor S, Mohammadi M, et al. Prevalence of stress, anxiety, depression among the general population during the COVID-19 pandemic: A systematic review and metaanalysis. Global Health. 2020;16:57. https://doi.org/10.1186/ s12992-020-00589-w

PMid:32631403

4. Kemenkes RI. Pedoman Pencegahan dan Pengendalian Corona Virus Deases (COVID-19) Revisi KE-5. Vol. 5. Kemenkes RI: Indonesia; 2020. https://covid19.go.id/p/protokol/ pedoman-pencegahan-dan-pengendalian-coronavirus-diseasecovid-19-revisi-ke-5 [Last accessed on 2021 May 25]. https:// doi.org/10.32922/jkp.v8i2

5. Ophinni Y, Hasibuan AS, Widhani A, Maria S, Koesnoe $S$ Yunihastuti E, et al. COVID-19 vaccines: Current status and implication for use in Indonesia. Acta Med Indones. 2020;52(4):388-412.

PMid:33377885

6. Wang C, Pan R, Wan X, Tan Y, Xu L, Ho CS, et al. Immediate psychological responses and associated factors during the initial stage of the 2019 Coronavirus disease (COVID-19) epidemic among the general population in China. Int J Environ Res Public Health. 2020;17(5):1729. https://doi.org/10.3390/ ijerph17051729

PMid:32155789

7. Alyami M, de Albuquerque J, Krägeloh $\mathrm{C}$, Alyami H, Henning M Effects of fear of COVID-19 on mental well-being and quality of life among Saudi Adults: A path analysis. Saudi J Med Med Sci. 2021;9(1):24-30. https://doi.org/10.4103/sjmms.sjmms_630_20 PMid:33519340

8. Karataş Z, Tagay Ö. The relationships between resilience of the adults affected by the COVID pandemic in Turkey and COVID-19 fear, meaning in life, life satisfaction, intolerance of uncertainty and hope. Pers Individ Dif. 2021;172:110592. https://doi.org/10.1016/j.paid.2020.110592

PMid:33518871

9. Nakhostin-Ansari A, Sherafati A, Aghajani F, Khonji MS Aghajani R, Shahmansouri N. Depression and anxiety among Iranian medical students during COVID-19 pandemic. Iran J Psychiatry. 2020;15(3):228-35. https://doi.org/10.18502/ijps. v15i3.3815

PMid:33193771

10. Filho $\mathrm{Cl}$, Rodrigues WC, de Castro RB, Marçal AA, Pavelqueires S, Takano L, et al. Impact of COVID-19 Pandemic on Mental Health of Medical Students: A Cross-Sectional Study Using GAD-7 and PHQ-9 Questionnaires (Preprint); 2020. https://doi.org/10.1101/2020.06.24.20138925

11. Pandey U, Corbett G, Mohan S, Reagu S, Kumar S, Farrell T, et al. Anxiety, depression and behavioural changes in junior doctors and medical students associated with the coronavirus pandemic: A cross-sectional survey. J Obstet Gynaecol India. 2021;71(1):1-5. https://doi.org/10.1007/s13224-020-01366-w PMid:32989348

12. Vala N, Vachhani M, Sorani A. Study of anxiety, stress, and depression level among medical students during COVID-19 pandemic phase in Jamnagar city. Natl J Physiol Pharm Pharmacol. 2020;10(12):1-3. https://doi.org/10.5455/ njppp.2020.10.07205202031072020

13. Lasheras I, Gracia-Garcia P, Lipnicki DM, Bueno-Notivol J, López-Antón $\mathrm{R}$, de la Cámara $\mathrm{C}$, et al. Prevalence of anxiety in medical students during the COVID-19 pandemic: A rapid 
systematic review with meta-analysis. Int $\mathrm{J}$ Environ Res Public Health. 2020;17(18):6603. https://doi.org/10.3390/ ijerph17249353

PMid:32927871

14. Saraswathi I, Saikarthik J, Kumar KS, Srinivasan KM, Ardhanaari M, Gunapriya R. Impact of COVID-19 outbreak on the mental health status of undergraduate medical students in a COVID-19 treating medical college: A prospective longitudinal study. PeerJ. 2020;8:e10164. https://doi.org/10.7717/ peerj. 10164

PMid:33088628

15. Torun F, Torun SD. The psychological impact of the COVID-19 pandemic on medical students in Turkey. Pak J Med Sci. 2020;36(6):1355-9. https://doi.org/10.12669/pjms.36.6.2985 PMid:32968408

16. Prayogi AR, Hardini PP, Alamiyyah M, Sari KI, Haqi DN, Sari JD. Determinan tingkat depresi mahasiswa pada masa pandemi COVID-19 (studi kasus mahasiswa Universitas Airlangga Surabaya). J CMHP. 2020;2(2):1-7. https://doi.org/10.51602/ cmhp.v2i2.42

17. Santoso A, Ardi WR, Prasetya RL, Dwidiyanti M, Wijayanti DY, Mu'in M, et al. Tingkat depresi mahasiswa keperawatan di tengah wabah COVID-19. J Holist Nurs Health Sci. 2020;3(1):1-8. https://doi.org/10.14710/hnhs.3.1.2020.1-8

18. Hasanah U, Fitri NL, Supardi S, Livana PH. Depresi pada mahasiswa selama masa pandemi COVID-19. J Keperawatan Jiwa. 2020;8(4):421-4. https://doi.org/10.26714/ jkj.8.4.2020.421-424

19. Nurhidayati T, Rahayu DA, Alfiyanti D. Nursing students' coping for burnout and fatigue online learning during Coronavirus disease 2019 pandemic. Open Access Maced J Med Sci. 2021;9(t4):92-6. https://doi.org/10.3889/oamjms.2021.5857

20. Arundina A, Tejoyuwono T, Nugraha RP, Fahdi FK. Phbs implementation and personal factors of medical students during the COVID-19 pandemic period. Eur J Mol Clin Med. 2020;7(10):1499-510.

21. Kinanthi MR, Listiyandini RA, Amaliah US, Ramadhanthy R, Farhan M. Adaptasi alat ukur DASS-21 versi Indonesia pada populasi mahasiswa. In: Seminar Nasional Psikologi; 2020. https://doi.org/10.7454/jps.2018.14

22. Mardea NA, Kristina SA. Stress levels and quality of life among pharmacy students in Yogyakarta, Indonesia. Int J Pharm Res. 2020;12(2):700-7.

23. Roy D, Tripathy S, Kar SK, Sharma N, Verma SK, Kaushal V. Study of knowledge, attitude, anxiety and perceived mental healthcare need in Indian population during COVID-19 pandemic. Asian J Psychiatr. 2020;51:102083. https://doi. org/10.1016/j.ajp.2020.102083 PMid:32283510

24. Maulida H, Jatimi A, Heru MJA, Munir Z, Rahman HF. Depresi pada komunitas dalam menghadapi pandemi COVID-19: a systematic review. JSK. 2019;2(4):519-24. https://doi. org/10.25026/jsk.v2i4.201.

25. The World Health Organization Quality of Life assessment (WHOQOL): position paper from the World Health Organization. Soc Sci Med. 1995;41(10):1403-9. https://doi. org/10.1016/0277-9536(95)00112-k00112-k

PMid: 8560308

26. Mukhtar S. Pakistanis' mental health during the COVID-19. Asian J Psychiatr. 2020;51:102127. https://doi.org/10.1016/j. ajp.2020.102127 PMid:32344330

27. Shan AA, Sadia RS, Malik IM, Javed R, Shabbir S, Fakhri $\mathrm{MH}$, et al. COVID-19 pandemic causing mental stress: A cross sectional study to evaluate the level of anxiety and its sources among medical undergraduates of gujranwala medical college.
World J Pharm Med Res. 2020;6(7):270-6. Available from: https://www.wjpmr.com/home/article_abstract/2867. [Last accessed on 2021 May 25].

28. Saddik B, Hussein A, Sharif-Askari FS, Kheder W, Temsah MH, Koutaich RA, et al. Increased levels of anxiety among medical and non-medical university students during the COVID-19 pandemic in the United Arab Emirates. Risk Manag Healthc Policy. 2020;13:2395-406. https://doi. org/10.1101/2020.05.10.20096933

PMid:33177898

29. Cao W, Fang Z, Hou G, Han M, Xu X, Dong J, et al. The psychological impact of the COVID-19 epidemic on college students in China. Psychiatry Res. 2020;287:112934. https:// doi.org/10.1016/j.psychres.2020.112934

PMid:32229390

30. Shah SM, Mohammad D, Qureshi MF, Abbas MZ, Aleem S. Prevalence, psychological responses and associated correlates of depression, anxiety and stress in a global population, during the coronavirus disease (COVID-19) pandemic. Community Ment Health J. 2021;57(1):101-10. https://doi.org/10.1007/ s10597-020-00728-y

PMid:33108569

31. Brooks SK, Webster RK, Smith LE, Woodland L, Wessely S, Greenberg $\mathrm{N}$, et al. The psychological impact of quarantine and how to reduce it: Rapid review of the evidence. Lancet. 2020;395(10227):912-20. https://doi.org/10.1016/ s0140-6736(20)30460-8

PMid:32112714

32. Khasawneh Al, Humeidan AA, Alsulaiman JW, Bloukh $S$ Ramadan M, Al-Shatanawi TN, et al. Medical students and COVID-19: Knowledge, attitudes, and precautionary measures. A descriptive study from Jordan. Front Public Health. 2020;8:253. https://doi.org/10.3389/fpubh.2020.00253 PMid: 32574313

33. Xiao H, Shu W, Li M, Li Z, Tao F, Wu X, et al. Social distancing among medical students during the 2019 Coronavirus disease pandemic in China: Disease awareness, anxiety disorder, depression, and behavioral activities. Int J Env Res Public Health. 2020;17(14):5047. https://doi.org/10.3390/ijerph17145047 PMid:32674285

34. Haqi MH, Misbahatul E, Bahiyah K. The description of mental status (stress, anxiety, and depression) on post earthquake victims based on the development period (adolescents, adult, and elderly) in desa pendua kabupaten lombok utara. Psychiatry Nurs J. 2019;1(2):29-35. https://doi.org/10.20473/ pnj.v1i1.13013

35. Özdin S, Özdin ŞB. Levels and predictors of anxiety, depression and health anxiety during COVID-19 pandemic in Turkish society: The importance of gender. Int J Soc Psychiatry. 2020;66(5):504-11. https://doi.org/10.1177/0020764020927051 PMid:32380879

36. Abdel Wahed WY, Hassan SK. Prevalence and associated factors of stress, anxiety and depression among medical Fayoum University students. Alexandria J Med. 2017;53(1):77-84. https://doi.org/10.1016/j.ajme.2016.01.005

37. Saravanan C, Wilks R. Medical students experience of and reaction to stress: The role of depression and anxiety. ScientificWorldJournal. 2014;2014:737382.

38. Younas S, Tahir F, Sabih F, Hussain R, Hassan A, Sohail M, et al. Psychological capital and mental health: Empirical exploration in perspective of gender. PONTE Int Sci Res J. 2020;76(1/1):150-75. https://doi.org/10.21506/j.ponte.2020.1.11

39. Singh K, Junnarkar M, Sharma S. Anxiety, stress, depression, and psychosocial functioning of Indian adolescents. Indian J Psychiatry. 2015;57(4):367-74. https://doi. org/10.4103/0019-5545.171841 


\section{PMid:26813517}

40. Nurrezki S, Irawan R. Hubungan stres, cemas, dan depres dengan kejadian migrain pada mahasiswa kedokteran di Jakarta. Damianus J Med. 2020;19(1):1-7. https://doi.org/10.25170/djm. v19i1.1200

41. Abdulghani HM, Sattar K, Ahmad T, Akram A. Association of COVID-19 pandemic with undergraduate medical students' perceived stress and coping. Psychol Res Behav Manag. 2020;13:871-81. https://doi.org/10.2147/prbm.s276938 PMid:33154682

42. Arslan G, Yıldırım M. Coronavirus stress, meaningful living, optimism, and depressive symptoms: A study of moderated mediation model. Aust J Psychol. 2021;3(2):1-12. https://doi. org/10.31234/osf.io/ykvzn

43. Fitriasari A, Septianingrum $Y$, Budury $S$, Khamida K. Online learning stress relates to student coping strategies during the COVID-19 Pandemic. J Keperawatan. 2020;12(4):985-92.

44. Sasikala T, Sahoo S, Lakshmanna N. Effect of COVID-19 crisis on medical students. Int J Res Med Sci. 2020;8(7):2714-7. https://doi.org/10.18203/2320-6012.ijrms20202924

45. Yıldırım M, Akgül Ö, Geçer E. The effect of COVID-19 anxiety on general health: The role of COVID-19 coping. Int J Ment Health Addict. 2021;11:1-12. https://doi.org/10.1007/ s11469-020-00429-3

PMid:33456406

46. Zhu W, Wei Y, Meng X, Li J. The mediation effects of coping style on the relationship between social support and anxiety in Chinese medical staff during. BMC Health Serv Res. 2020;20(107):1-7. https://doi.org/10.1186/s12913-020-05871-6

47. Yıldırım M, Arslan G, Özaslan A. Perceived risk and mental health problems among healthcare professionals during COVID19 pandemi: exploring the mediating effects of resilience and coronavirus fear. Int J Ment Health Addiction. 2020: Nov 16:1-11. https://doi.org/10.1007/s11469-020-00424-8 PMid:33223977

48. Kim SC, Sloan C, Montejano A, Quiban C. Impacts of coping mechanisms on nursing students' mental health during COVID-19 lockdown: A cross-sectional survey. Nurs Rep. 2021;11(1):36-44. https://doi.org/10.3390/nursrep11010004

49. Gallego J, Aguilar-Parra JM, Cangas AJ, Langer Ál, Mañas I. Effect of a mindfulness program on stress, anxiety and depression in university students. Span J Psychol. 2014;17:E109. https:// doi.org/10.1017/sjp.2014.102

\section{PMid:26055051}

50. Bustamam N, Theresa RM, Wahyuningsih S. Student support program to reduce stress, anxiety, and depression on medical students. J Pendidikan Kedokteran Indones. 2020;9(2):170-81. https://doi.org/10.22146/jpki.51245

51. Chtourou H, Trabelsi K, H'Mida C, Boukhris O, Glenn JM, Brach $\mathrm{M}$, et al. Staying physically active during the quarantine and self-isolation period for controlling and mitigating the COVID-19 pandemic: A systematic overview of the literature. Front Psychol. 2020;11:1708. https://doi.org/10.3389/ fpsyg.2020.01708

52. Steve D, Amisi MD, Punuh MI. Gambaran aktivitas fisik mahasiswa semester II fakultas kesehatan masyarakat universitas sam ratulangi saat pembatasan sosial masa pandemi COVID-19. KESMAS. 2021;10(1):95-104. Available from: https://ejournal.unsrat.ac.id/index.php/kesmas/article/ view/32228.

53. Balhara YPS, Kattula D, Singh S, Chukkali S, Bhargava R. Impact of lockdown following COVID-19 on the gaming behavior of college students. Indian J Public Health. 2020;64:S172-6. https://doi.org/10.4103/ijph.ijph_465_20

54. Yıldırım M, Arslan G, Alkahtani AM. Do fear of COVID-19 and religious coping predict depression, anxiety, and stress among the Arab population during health crisis? Death Stud. 2021:1-7. https://doi.org/10.1080/07481187.2021.1882617

55. Djalante R, Lassa J, Setiamarga D, Sudjatma A, Indrawan M, Haryanto $\mathrm{B}$, et al. Review and analysis of current responses to COVID-19 in Indonesia: Period of January to March 2020. Prog Disaster Sci. 2020;6:100091. https://doi.org/10.1016/j. pdisas.2020.100091

56. Amelia N, Rahmah S, Harahap SN. Peran agama dalam mengatasi kecemasan masyarakat terkait pandemi COVID-19. J Abdi Mas Adzkia. 2021;1(2):90-107. Available from: http:// jurnal.uinsu.ac.id/index.php/adzkia/article/view/8841. [Last accessed on 2021 May 25].

57. AzaniaD, Naan. Peran spiritual bagikesehatanmentalmahasiswa di tengah pandemi COVID-19. Humanistika J Keislaman. 2021;7(1):26-44. https://doi.org/10.36835/humanistika. v7i1.384.

58. Syahrir A, Rahem A, Prayoga A. Religiosity of pharmacy students of UIN Malang during COVID-19 pandemic. J Halal Prod Res. 2020;3(1):25-34. https://doi.org/10.20473/jhpr. vol.3-issue.1.25-34 